\title{
Complement factor $H$ levels in steady state sickle cell anaemia
}

\author{
Olutogun T.A. ${ }^{1}$, *Olufemi-Aworinde K.J. ${ }^{1}$, Fasola F.A. ${ }^{2}$, Ano-Edward G.H. ${ }^{3}$, \\ Aworinde 0.O. ${ }^{4}$, and Ajiboye A.O. ${ }^{5}$
}

\begin{abstract}
Objective: The red cell membrane of sickle cell anaemia is vulnerable to attack from the alternative complement pathway. The activation of the alternative complement pathway is initiated by externalization of phosphatidylserine on red cell membrane. Serum and cell bound regulators normally prevent amplification of the cascade. However, red blood cells in sickle cell anaemia appear to be exposed and the cell lysing membrane attack complex is ubiquitous on irreversible sickle red blood cells. It is possible that there are deficiencies (either functional or quantitative) of complement regulators. In this study the quantitative defects of the most abundant serum phase regulator, complement factor $\mathrm{H}$ in sickle cell anaemia was investigated.
\end{abstract}

Methods: We compared the plasma levels of complement factor $\mathrm{H}$ (a serum phase regulator of the alternative pathway) in 61 steady state $\mathrm{Hb}$ SS with 60 healthy $\mathrm{Hb}$ AA using an enzyme linked immunosorbent assay to analyze complement factor $\mathrm{H}$ level in the plasma. The full blood count parameters were estimated using flow cytometry.

Results: There was no significant difference in the serum complement factor $\mathrm{H}$ levels between the steady state $\mathrm{Hb} \mathrm{SS}$ and healthy $\mathrm{Hb} \mathrm{AA}$. Significant inverse relationships existed between complement factor $\mathrm{H}$, total white cell count, granulocyte cell count and platelet count as well as significant direct relationships between complement factor $\mathrm{H}$, haematocrit, and the haemoglobin concentration.

Conclusion: Complement factor $\mathrm{H}$ in patients with sickle cell anaemia who are in steady state is not significantly lower than in controls.

Keywords: Complement factor $\mathrm{H}$, sickle cell anaemia, alternative pathway

\author{
*Correspondence author \\ Olufemi-Aworinde K.J. \\ http://orcid.org/0000-0002-4287-8140 \\ Email: kehindejoyce"yahoo.com \\ ${ }^{1}$ Department of Haematologyand Blood transfusion, Bowen University, Iwo, Nigeria. \\ ${ }^{2}$ Department of Haematologyand Blood transfusion, UCH, Ibadan, Nigeria. \\ ${ }^{3}$ Department of Hispathology, Bowen University, Iwo, Nigeria. \\ ${ }^{4}$ Department of Obstetrics and Gyneacology, Bowen University, Iwo, Nigeria. \\ ${ }^{5}$ Department of Surgery, Bowen University, Iwo, Nigeria.
}




\title{
Les niveaux du facteur $H$ du complément dans l'état stable de la drépanocytose.
}

\author{
Olutogun T.A. ${ }^{1}$, *Olufemi-Aworinde K.J. ${ }^{1}$, Fasola F.A. ${ }^{2}$, Ano-Edward G.H. ${ }^{3}$, \\ Aworinde 0.O. ${ }^{4}$, and Ajiboye A.O. ${ }^{5}$
}

\begin{abstract}
Résumé
Objectif: La membrane érythrocytaire de la drépanocytose est vulnérable aux attaques provenant de la voie alterne. L'activation de la voie alterne est initiée par l'extériorisation de la phosphatidylsérine sur la membrane érythrocytaire. Le sérum et la cellule sont des régulateurs liés pour prévenir généralement l'amplification de la cascade. Cependant, les globules rouges atteints de drépanocytose apparaissent comme étant exposés et le complexe d'attaque membranaire de la lyse cellulaire est omniprésent dans le cas de l'anémie falciforme irréversible. Il est possible qu'il y ait des déficiences (soit fonctionnelles, soit quantitatives) de régulateurs du complément. Dans cette étude, les défauts quantitatifs du sérum le plus abondant de la phase régulatrice, le facteur $\mathrm{H}$ du complément dans la drépanocytose, ont été examinés.
\end{abstract}

Méthodes: Nous avons comparé le taux plasmatique du facteur $\mathrm{H}$ du complément (un sérum régulateur de phase de la voie alterne) chez 61 états stables $\mathrm{Hb}$ SS disposant de $60 \mathrm{Hb}$ AA sains, en utilisant la méthode immuno-enzymatique pour analyser le niveau du facteur $\mathrm{H}$ du complément dans le plasma. La numérotation globulaire (hémogramme) a été estimée en utilisant la cytométrie en flux.

Résultats : Il n'y a pas de différence significative en ce qui concerne les niveaux du sérum facteur $\mathrm{H}$ du complément, entre l'état stable $\mathrm{Hb} \mathrm{SS}$ et le $\mathrm{Hb}$ AA sain. A l'inverse, un lien significatif existe entre le facteur $\mathrm{H}$ du complément, le nombre total de globules blancs, de granulocytes et de plaquettes. Une relation significative directe est également établie entre le facteur $\mathrm{H}$ du complément, l'hématocrite et la concentration d'hémoglobine.

Conclusion : le facteur $\mathrm{H}$ du complément chez les patients en état stable atteints de drépanocytose est guère inférieur à celui enregistré lors des contrôles.

Mots-clés : facteur H du complément, drépanocytose, voie alterne

*Correspondence author

Olufemi-Aworinde K.J.

http://orcid.org/0000-0002-4287-8140

Email: kehindejoyce"yahoo.com

${ }^{1}$ Department of Haematologyand Blood transfusion, Bowen University, Iwo, Nigeria.

${ }^{2}$ Department of Haematologyand Blood transfusion, UCH, Ibadan, Nigeria.

${ }^{3}$ Department of Hispathology, Bowen University, Iwo, Nigeria.

${ }^{4}$ Department of Obstetrics and Gyneacology, Bowen University, Iwo, Nigeria.

${ }^{5}$ Department of Surgery, Bowen University, Iwo, Nigeria.

Research Journal of Health Sciences subscribed to terms and conditions of Open Access publication. Articles are distributed under the terms of Creative Commons Licence (CC BY-NC-ND 4.0). (http://creativecommons.org/licences/by-nc-nd/4.0)

http://dx.doi.org/10.4314/rejhs.v6i1.4 


\section{INTRODUCTION}

The sickle cell anaemia individual endures lifelong haemolysis due to the formation of insoluble haemoglobin $\mathrm{S}$ polymers and irreversible damage to the red cell membrane, punctuated by intermittent acute crises which culminates in chronic end organ damage (1). The cause of sickle cell anaemia is the homozygous inheritance of the sickle gene. The sickle gene is a point mutation in the beta globin gene on exon 1 resulting in a change from GAG to GTG (2). The resulting sickle haemoglobin has replaced glutamic acid with valine at position 6 of the beta globin polypeptide (3). The sickle haemoglobin forms polymers under conditions of deoxygenation. Within milliseconds to seconds these polymers grow exponentially (4). Although on re-exposure to oxygen the polymers dissolve, repeated cycles of oxygenation and deoxygenation makes the polymers insoluble and rigid (5). The rigid form of the $\mathrm{S}$ polymer damages the red cell membrane, and assumes an irreversibly sickled shape (6). Furthermore, damaged red cell membrane exteriorizes phosphatidylserine to the external surface of the erythrocyte membrane $(6,7)$. The activation of complement pathway is accelerated by the abnormally situated phosphatidyl serine on the external surface of the red cell membrane (8). Plasma C3 levels are consumed and activator complement proteins specific to the alternative pathway- Factor B is significantly depleted in sickle cell anaemia (8). On dense and irreversibly sickled red cells, increased amounts of $\mathrm{C} 5_{\mathrm{b}}-\mathrm{C} 7$ and $\mathrm{C} 9$ (components of the membrane attack complex) confirms the amplification and completion of the alternative complement pathway (9). Exposure of red blood cells to activated complement proteins can lead either to extravascular haemolysis as occurs in immune mediated haemolytic anaemia or intravascular haemolysis as occurs in Paroxysmal nocturnal haemoglobinuria $(10,11)$.

The complement pathway is a part of our bodies innate defence system. It monitors the blood, attacking and removing foreign bodies and organisms. The system is made up of 30 soluble proteins which circulate as inactive precursors (12). Once activated with the aid of convertases, the system is propagated through three pathways (the classical, the lectin and the alternative pathway) (13). The alternative complement pathway is initiated by spontaneous hydrolysis of C3's internal thioester bond. It occurs on both host and foreign cells. The hydrolysed $\mathrm{C} 3(\mathrm{H} 2 \mathrm{O})$ together with proteins Factor $\mathrm{B}$ and $\mathrm{D}$ form C3convertase ( $\mathrm{C} 3 \mathrm{H} 2 \mathrm{OBb})$. The $\mathrm{C} 3$ convertase cleaves $\mathrm{C} 3$ to $\mathrm{C} 3 \mathrm{a}$ and $\mathrm{C} 3 \mathrm{~b}$. $\mathrm{C} 3 \mathrm{~b}$ binds to host surfaces and sets up an amplification loop where many more $\mathrm{C} 3 \mathrm{~b}$ are produced which couple with Factor $\mathrm{B}$. $\mathrm{C} 3 \mathrm{bBb}$ together with properdin (from neutrophils) forms $\mathrm{C} 5$ convertase which cleaves $\mathrm{C} 5$ to $\mathrm{C} 5 \mathrm{a}$ and $\mathrm{C} 5 \mathrm{~b}$.(14) The $\mathrm{C} 5 \mathrm{~b}$ joins $\mathrm{C} 3 \mathrm{BbP}$ to activate $\mathrm{C} 6, \mathrm{C} 7, \mathrm{C} 8$ and they result in the assembly of C9 into the Membrane Attach Complex that creates a pore in the cell (14). See Figure 1

Because the alternate pathway has a spontaneous tick over mechanism, $\mathrm{C} 3 \mathrm{~b}$ is deposited on both host and pathogen surfaces alike. When alternate complement system is activated on sickle cells initiated by the externalization of phosphatidyl serine, homeostatic mechanisms specific to the alternative pathway should kick in. Factor $\mathrm{H}$ is one of the most important plasma complement regulators (15). Factor $\mathrm{H}$ regulates the binding of hydrolysed $\mathrm{C} 3, \mathrm{C} 3(\mathrm{H} 2 \mathrm{O})$ and $\mathrm{C} 3 \mathrm{bBb}$ by promoting their rapid decay and short-circuiting the amplification loop. It works with factor I (a cell bound regulator) to inactivate any $\mathrm{C} 3 \mathrm{~b}$ that escaped the initial deactivation., In effect, the terminal cascade is shut down. Factor $\mathrm{H}$ is catalyzed in its regulatory activity and concentration rapidly decreases where ever widespread inactivation of $\mathrm{C} 3$ convertase is required (12). In atypical haemolytic uraemic syndrome (aHUS), age-related macular degeneration (AMD) and membranoproliferative glomerulonephritis (MPGN), mutations of complement factor $\mathrm{H}$ results in the deposition of $\mathrm{C} 3 \mathrm{~b}$ on membranes of the retina and glomeruli (16). Quantitative complement factor $\mathrm{H}$ deficiency (CFHD) manifests as asymptomatic, recurrent bacterial infections, and renal failure (17).

In sickle cell anaemia, evidence of alternative complement pathway activation observed include the following: $\mathrm{C} 3 \mathrm{~b}$ is bound to sickle erythrocytes membrane (6), Factor B and Factor D concentrations (specific to the alternate pathway) reduced to half that of normal controls (18). Our hypothesis is that complement factor $\mathrm{H}$ is depleted in sickle cell anemia while playing its regulatory role. In view of the aforementioned, we measured complement factor $\mathrm{H}$ in sickle cell anemia patients and compared with controls to see if this regulator is truly depleted. 


\section{MATERIALS AND METHODS}

Study population: Sixty-one (61) adult haemoglobin-S patients in steady state and 60 healthy age and sex matched adult haemoglobinA blood donors from the Oyo State Blood Bank, as well as volunteer medical and nursing staff were recruited. The ages of the sickle cell patients range between 14 and 52 years while those of the controls were between 15 and 60 years. The study was conducted over a 3-month period. Haemoglobin electrophoresis were confirmed using Agarose gel electrophoresis at alkaline $\mathrm{pH}$ of 8.4. Steady-state was defined as having no blood transfusions in the previous four months and absence of acute episodes of the following; infection, vaso-occlusive crises, acute coronary syndrome, stroke, priapism, acute splenic sequestration for at least one month before inclusion in the study (19). Sickle cell anaemia patients with a diagnosis of glomerulonephritis or age related macular degeneration were excluded from the study.

Ethical Considerations: Ethical approval was obtained from the Oyo State Research and Ethics Committee.

Sample collection and analysis: Informed consent was obtained from the participants. Interviewer administered questionnaires were used to obtain information on socio-demographic and clinical characteristics such as previous admissions for febrile illnesses and blood transfusion from study participants. Five millilitres of venous blood were collected into each of 2 different pottasium ethylene diaminetetra acetic (K EDTA) bottles for full blood count (FBC) and complement Factor $\mathrm{H}$ analysis respectively. The blood sample for complement factor $\mathrm{H}$ analysis was centrifuged at $2000 \mathrm{~g}$ for five minutes within 30 minutes of collection. The plasma was decanted using a plastic pipette and stored at $-20^{\circ} \mathrm{C}$ till analysis. The plasma complement factor $\mathrm{H}$ level was determined by the enzyme linked immunosorbent assay method using the abcam ab137975 Factor H Human ELISA kit (abcam Limited UK).

Statistical analysis: Student t- test was used to compare the mean of Complement Factor $\mathrm{H}$. Correlation testing was carried out using the Pearson's correlation test on complement factor $\mathrm{H}$ and full blood count.

\section{RESULTS}

A total of 121 subjects participated in the study. These included 61 patients with sickle cell anaemia and 60 haemoglobins A controls. The mean age of the patients was $24.5 \pm 10.1$ and the control was $24.5 \pm 6.6$ (Table1). Clinical characteristics of patients with sickle cell anaemia are shown in table 2 and ninety point two percent $(90.2 \%)$ of the patients had ever been hospitalised while sixty point seven percent $(60.7 \%)$ of the patients had ever been transfused. Table 3 shows the mean of the haematological parameters of both patients and controls. Complement factor $\mathrm{H}$ value was slightly lower in the SCA patients compared with the controls and it was not statistically significant $(\mathrm{p}=0.14)$. (Table 4) There was no significant relationship between complement factor $\mathrm{H}$ and clinical features of patients (Table 5). The white cell count and granulocyte counts had a significant negative correlation with complement factor $\mathrm{H}$ $(\mathrm{p}=0.0002$ and $\mathrm{p}=0.002$ respectively) (Table 6). There was greater variability in the complement factor $\mathrm{H}$ levels among the controls compared with the patients (Figure 2).

\section{DISCUSSION}

This study compared the complement factor $\mathrm{H}$ level of patients with sickle cell anaemia with controls and found that there was no significant difference between SCA and controls. In sickle cell anaemia there is persistent, increased activation of the alternate system which progresses to formation of the membrane attack complex on the sickled red cells. This is clear from the reduction of alternative pathway activator protein factor $\mathrm{B}$ and $\mathrm{D}$ and $\mathrm{C} 3 \mathrm{~b}$ coated red cell (particularly the dense and irreversibly sickle red blood cells) found in these groups of patients. We therefore assayed the most abundant regulatory protein of the alternative complement system complement factor $\mathrm{H}$ that works both in the fluid and the cell bound phase. Recent findings shows that deficiencies and mutations in the structure of the complement factor $\mathrm{H}$ results in deposition of $\mathrm{C} 3 \mathrm{~b}$ on tissue surfaces and extracellular matrices (20). Because sickle cell anaemia has both a decrease in serum factor B and increased $\mathrm{C} 3 \mathrm{~b}$ present on red cell membranes we surmised that, like atypical haemolytic uremic syndrome or membranoproliferative glomerulonephritis, the answer may lie in either a quantitative or qualitative deficiency of complement factor $\mathrm{H}$ (21). From this study, however, complement factor $\mathrm{H}$ levels are not 
significantly lower among sickle cell anaemia individuals and haemoglobin A controls. The persistence activation of the alternative complement activation is not associated with quantitative deficiencies in complement factor $\mathrm{H}$ levels. The factor $\mathrm{H}$ levels are comparable with those of normal individuals who do not have $\mathrm{C} 3 \mathrm{~b}$ on red cell surfaces. For one thing, it reassures the researchers that regulatory mechanisms of the complement pathway in sickle cell anaemia remain intact. On the other hand, the fact that complement factor $\mathrm{H}$ is not reduced in sickle cell anaemia suggest that the sheer number of the $\mathrm{C} 3 \mathrm{~b}$ molecules bound to sickle erythrocytes defies total regulation. These may provide research questions for the future.

We found that there was higher variability of complement factor $\mathrm{H}$ levels in the controls compared with SCA. Apparently healthy control may have a higher variability in their genetic material or a greater variability in the external environment which they inhabit compared with the haemoglobin S population sampled in this study.

The white cell count and neutrophil count was inversely related to Factor $\mathrm{H}$. Zwede et al found that an important initiator of the alternative complement pathway was neutrophil produced properidine (13). They found that properdine acts to stabilize the alternative pathway and is a positive regulator of the alternate pathway. If properdine concentrations are increased, the amplification of the alternative complement pathway is assured. An inverse relationship between the white cells and complement factor suggests that the alternative complement pathway aided by properdine outstrips the regulatory mechanisms. Prior to this study no relationship has been documented between haematological parameters and complement factor $\mathrm{H}$ amongst sickle cell anaemia patients.

There was also a negative correlation between complement factor $\mathrm{H}$ and platelet count although the correlation was not statistically significant. Miao et al describes the role of platelets in immunology through their ability to bind complement proteins, and initiate complement activation (22). The negative correlation between platelet count and complement factor $\mathrm{H}$ is an example of the complement activation that overwhelms regulatory mechanisms. We discovered significant direct relationship between haematocrit, haemoglobin concentration and complement factor $\mathrm{H}$ concentrations. This suggests that complement induced haemolysis plays a role in the aetiology of anaemia in sickle cell anaemia. If the complement cascade is kept under tight control, complement mediated lysis is minimized. Higher MCV values were also found to be associated with lower complement factor $\mathrm{H}$ level. The exact pathophysiologic mechanism is yet to be elucidated and provides interesting research questions in the relationship between the alternative complement pathway and sickle cell anaemia for the future.

Conflict of interest: The authors declare no conflict of interest.

\section{REFERENCES}

1. Brousse V, Makani J, Rees DC. Management of sickle cell disease in the community. BMJ. 2004; 348: 1765 .

2. Ballas SK, Kesen MR, Goldberg MF, et al. Beyond the Definitions of the Phenotypic Complications of Sickle Cell Disease: An Update on Management. The Scientific World Journal. 2012; 2012:949535. doi:10.1100/2012/949535

3. Steinberg $\mathrm{MH}$. Sickle cell anemia, the first molecular disease: overview of molecular etiology, pathophysiology, and therapeutic approaches. The Scientific World Journal. 2008; 8:1295-1324. DOI:10.1100/tsw.2008.157

4. Eaton, W.A. and Hofrichter, J. Sickle cell hemoglobin polymerization. Adv. Protein Chem. 1998; 40,63-280.

5. Lei H, Karniadakis GE. Predicting the morphology of sickle red blood cells using coarse-grained models of intracellular aligned hemoglobin polymers. Soft matter. $2012 ; 8$ (16):10.1039/C 2 S M $07294 \mathrm{G}$. doi:10.1039/C2SM07294G.

6. De Jong, K., Larkin, S.K., Styles, L.A., Bookchin, R.M., and Kuypers, F.A. Characterization of the phosphatidylserineexposing subpopulation of sickle cells. Blood. 2001; 98, 860-867.

7. Lubin, B., Kuypers, F., and Chiu, D.Lipid alterations and cellular properties of sickle red cells. Ann. N.Y. Acad. Sci.1989; 565, 86-95.

8. Wang RH, Phillips G, Medof ME, Mold C. Activation of the alternative complement p a t h w a y b e x p o s u r e of phosphatidylethanolamine and phosphatidylserine on erythrocytes from sickle cell disease patients. Journal of Clinical Investigation. 1993;92(3):1326-1335.

9. Test S,Woolworth V. Defective regulation of complement by the sickle erythrocyte: evidence for a defect in control of membrane attack complex formation. Blood, 1994. 83(3), 842-852.

10. Meulenbroek EM, de Haas M, Brouwer C, Folman C, Zeerleder SS, Wouters D. Complement deposition in autoimmune 
hemolytic anemia is a footprint for difficult-todetect IgM autoantibodies. Haematologica. 2015 ; $1000\left(\begin{array}{ll}1 & 1\end{array}\right): 1407-1414$. doi:10.3324/haematol.2015.128991.

11. DeZern AE, Brodsky RA. Paroxysmal Nocturnal Hemoglobinuria: A Complement-Mediated Hemolytic Anemia. Hematology/oncology clinics of North America. 2015;29(3):479-494. doi: 10.1016/j.hoc.2015.01.005.

12. Walport MJ. Complement. N Engl J Med. 2001; 344: 1140-1144.

13. Zewde N, Gorham RD, Jr., Dorado A, Morikis D. Quantitative Modeling of the Alternative Pathway of the Complement System. PLoS ONE .2016;11(3): e0152337.

14. Lubbers R, van Essen MF, van Kooten C, Trouw LA. Production of complement components by cells of the immune system. Clinical and Experimental Immunology. 2017;188(2):183194. doi:10.1111/cei.12952.

15. Morgan HP, Schmidt CQ, Guariento M, et al. Structural basis for engagement by complement factor $\mathrm{H}$ of $\mathrm{C} 3 \mathrm{~b}$ on a self-surface. Nature structural \& molecular biology. 2011;18(4):463470. doi:10.1038/nsmb.2018.

16. Pangburn M. Cutting Edge: Localization of the Host Recognition Functions of Complement Factor $\mathrm{H}$ at the Carboxyl-terminal. Implications of Hemolytic Uremic Syndrom. J Immunol.2002;169:4702-4706doi: https://doi.org/10.4049/jimmunol.169.9.4702

17. Leitao MF, Vilela MM, Rutz R, Grumach AS, Condino-Net A, Kirschfink $M$. complement factor I deficiency in a family with recurrent infections. Immunopharmacology.1997;38(12):207-213 https://doi.org/10.1016/S01623109(97)00080-5

18. Wilson WA, Hughes GR, Lachmann PJ. Deficiency of factor B of the complement system in sickle cell anaemia. British Medical Journal. 2003;1(6006):367-369.

19. Quirolo K, Vichinsky E. Haemoglobin disorders. In: Behrmen RE, Kliegman EM, Jenson HB (eds). Nelson Text Book of Paediatrics. 17th ed. Philadephia. Saunders Company 2004; 16231634

20. Atkinson JP, Goodship THJ. Complement factor $\mathrm{H}$ and the haemolytic uremic syndrome. JEM.2007;204(6):1245-1248 doi . 10.1084/JEM20070664

21. Kavanagh D, Goodship TH, Richards A. Atypical Hemolytic Uremic Syndrome. Seminars in Nephrology. 2013;33(6):508-530. doi: 10.1016/j.semnephrol.2013.08.003.

22. Miao D, Li D-Y, Chen M, Zhao M-H. Platelets are activated in ANCA-associated vasculitis via thrombin-PARs pathway and can activate the alternative complement pathway. Arthritis Research \& Therapy. 2017; 19:252. doi:10.1186/s13075-017-1458-y. 
Table 1: Sociodemographic characteristics of patients and control

\begin{tabular}{|c|c|c|c|c|c|c|}
\hline \multirow{2}{*}{$\begin{array}{l}\text { Sociodemographic } \\
\text { characteristics }\end{array}$} & \multicolumn{2}{|c|}{ Patients $n=61$} & \multicolumn{2}{|c|}{ Controls $n=60$} & \multirow[b]{2}{*}{$\mathbf{X}^{2}$} & \multirow[b]{2}{*}{ P value } \\
\hline & Number & $\begin{array}{l}\text { Percentage } \\
(\%)\end{array}$ & Number & $\begin{array}{l}\text { Percentage } \\
(\%)\end{array}$ & & \\
\hline \multicolumn{7}{|l|}{ Gender } \\
\hline Male & 24 & 40 & 20 & 33 & & \\
\hline Female & 37 & 60 & 40 & 67 & 0.48 & 0.49 \\
\hline \multicolumn{7}{|l|}{ Age group (years) } \\
\hline$=25$ & 35 & 57.4 & 49 & 81.7 & & \\
\hline $26-35$ & 19 & 31.1 & 7 & 11.7 & & \\
\hline $36-45$ & 3 & 4.9 & 2 & 3.3 & 9.26 & 0.06 \\
\hline $46-55$ & 3 & 4.9 & 2 & 3.3 & & \\
\hline$>56$ & & 1.6 & 0 & 0 & & \\
\hline Mean age \pm sd & \multicolumn{2}{|l|}{$24.5 \pm 10.1$} & \multicolumn{2}{|l|}{$24.5 \pm 6.6$} & 0.5 & 0.5 \\
\hline \multicolumn{7}{|l|}{ Tribe } \\
\hline Yoruba & 49 & 80.3 & 48 & 80 & & \\
\hline Others & 12 & 19.7 & 12 & 20 & 1.06 & 0.6 \\
\hline \multicolumn{7}{|l|}{ Educational status } \\
\hline None & 2 & 3.3 & 5 & 8.3 & & \\
\hline Primary & 6 & 9.8 & 1 & 1.7 & & \\
\hline Secondary & 39 & 63.9 & 2 & 3.3 & & \\
\hline Tertiary & 14 & 21 & 52 & 86.6 & 75.08 & $0.000 *$ \\
\hline
\end{tabular}

Table 2: Clinical characteristics of patients

\begin{tabular}{llll}
\hline Clinical characteristics & Response & Number & Percentage\% \\
\hline Fever in the last year & Yes & 25 & 41 \\
& No & 36 & 59 \\
Infection in the last year & Yes & 8 & 13.1 \\
& No & 53 & 86.9 \\
Type of infection & Urinary tract infection & 2 & 3.3 \\
& Upper respiratory tract & 6 & 9.8 \\
& infection & & \\
Transfusion history(ever) & Yes & 37 & 60.7 \\
& No & 24 & 39.3 \\
History of chronic leg ulcer & Yes & 3 & 4.9 \\
& No & 38 & 95.1 \\
History of hospitalization & Yes & & \\
(ever) & No & 55 & 90.2 \\
& & 6 & 9.8 \\
\hline
\end{tabular}


Table 3: Haematological Parameters of sickle cell anaemia patients and controls

\begin{tabular}{lllll}
\hline Full Blood count & $\begin{array}{l}\text { Study n=61 } \\
\text { mean(sd) }\end{array}$ & $\begin{array}{l}\text { Control } \\
\mathbf{n}=60 \\
\text { mean(sd) }\end{array}$ & T value & P value \\
\hline Haematocrit $(\%)$ & $24.3(6.2)$ & $37.3(6.7)$ & 11.09 & $0.00^{*}$ \\
Haemoglobin concentration $(\mathrm{g} / \mathrm{L})$ & $77.5(18.6)$ & $119.0(25.4)$ & 10.49 & $0.00^{*}$ \\
White blood cells $\left(\times 10^{9} / \mathrm{L}\right)$ & $12.8(4.6)$ & $5.7(1.8)$ & -11.06 & $0.00^{*}$ \\
Neutrophil count $\left(\times 10^{9} / \mathrm{L}\right)$ & $5.8(2.4)$ & $2.6(1.0)$ & -10.13 & $0.00^{*}$ \\
Lymphocyte count $\left(\times 10^{9} / \mathrm{L}\right)$ & $5.5(2.7)$ & $2.54(1.3)$ & -7.69 & $0.00^{*}$ \\
Monocyte count $\left(\times 10^{9} / \mathrm{L}\right)$ & $3.0(1.3)$ & $0.6(0.3)$ & -1.44 & 0.15 \\
Platelet count $\left(\times 10^{9} / \mathrm{L}\right)$ & $366(129)$ & $236(72)$ & -6.85 & $0.00^{*}$ \\
Mean Corpuscular Volume $(\mathrm{fL})$ & $91.3(10.7)$ & $83.9(5.9)$ & -4.70 & $0.00^{*}$ \\
Mean Corpuscular Haemoglobin $(\mathrm{pg})$ & $29.3(3.8)$ & $27.1(3.0)$ & -3.47 & $0.001^{*}$ \\
Mean Corpuscular Haemoglobin & $321(19)$ & $323(27.8)$ & 0.53 & 0.59 \\
Concentration $(\mathrm{g} / \mathrm{L})$ & & & & \\
\hline$* 0.05$ significant & & & & \\
$>0.05$ not Significant & & & &
\end{tabular}

Table 4: Complement Factor $H$ in sickle cell anaemia patients and controls

\begin{tabular}{lllll}
\hline Variables & $\begin{array}{l}\text { Sickle cell anaemia } \\
\text { mean(sd) }\end{array}$ & Controls mean(sd) & T test & P value \\
\hline Complement Factor H(ng/mL) & $2.4(1.3)$ & $2.8(1.6)$ & 1.5 & 0.14 \\
Total & 61 & 60 & & \\
\hline$<0.05$ *significant & & & & \\
$>0.05$ not significant & & &
\end{tabular}

Table 5: Association between plasma complement factor $H$ levels and clinical characteristics of sickle cell anaemia patients

\begin{tabular}{lll}
\hline Clinical characteristics & $\mathbf{X}^{2}$ value & P value \\
\hline $\begin{array}{l}\text { Previous hospital admission } \\
\begin{array}{l}\text { Positive history of fever in the last } \\
\text { year }\end{array}\end{array}$ & 56.4 & 0.5 \\
$\begin{array}{l}\text { History of infection in the last one } \\
\text { year }\end{array}$ & 56.6 & 0.5 \\
$\begin{array}{l}\text { History of blood transfusion in the } \\
\text { last year }\end{array}$ & 52.1 & 0.5 \\
$\begin{array}{l}\text { History of chronic liver disease } \\
*<0.05 \text { significant }\end{array}$ & 0.6 \\
$>0.05$ not Significant & & 0.3 \\
\end{tabular}


Table 6: Relationship between complement factor $\mathbf{H}$, and haematological parameters in sickle cell patients

\begin{tabular}{lll}
\hline Parameter & R & P value \\
\hline White blood cell count $\left(\times 10^{9} / \mathrm{L}\right)$ & -0.21 & $0.002^{*}$ \\
Lymphocyte count $(\mathrm{x} \mathrm{10} / \mathrm{L})$ & -0.07 & 0.44 \\
Monocyte count $\left(\mathrm{x} 10^{9} / \mathrm{L}\right)$ & -0.02 & 0.81 \\
Granulocyte count $\left(\times 10^{9} / \mathrm{L}\right)$ & -0.28 & $0.002^{*}$ \\
Haemoglobin $\mathrm{g} / \mathrm{L}$ & -0.16 & 0.08 \\
Haematocrit $\%$ & -0.14 & 0.13 \\
MCV $(\mathrm{fL})$ & -0.18 & 0.05 \\
MCH $(\mathrm{pg})$ & 0.07 & 0.45 \\
MCHC $(\mathrm{g} / \mathrm{dL})$ & 0.16 & 0.09 \\
Platelet count $\left(\mathrm{x} 10^{9} / \mathrm{L}\right)$ & -0.07 & 0.05 \\
\hline * 0.05 significant & \\
$>0.05$ not Significant & \\
MCV= mean corpuscular volume & \\
MCH= Mean corpuscular haemoglobin & \\
MCHC= mean corpuscular haemoglobin concentration
\end{tabular}

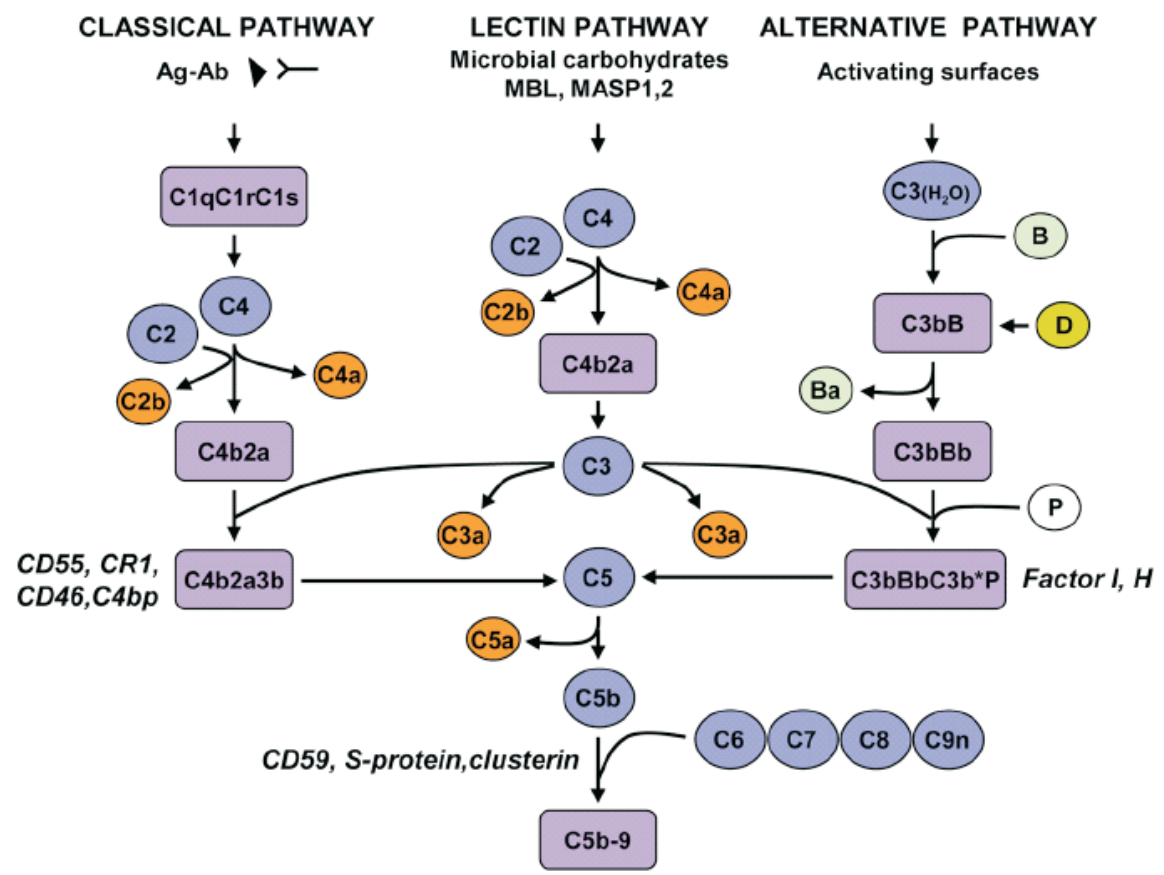

Fig 1: The initiation of the cascade of the complement pathway and its endpoint.

https://www.researchgate.net/profile/Horea_Rus/publication/51579775/figure/fig1/AS:285283066757120@ 1445028191660/Complement-activation-pathways-and-assembly-of-the-terminal-pathway.png 


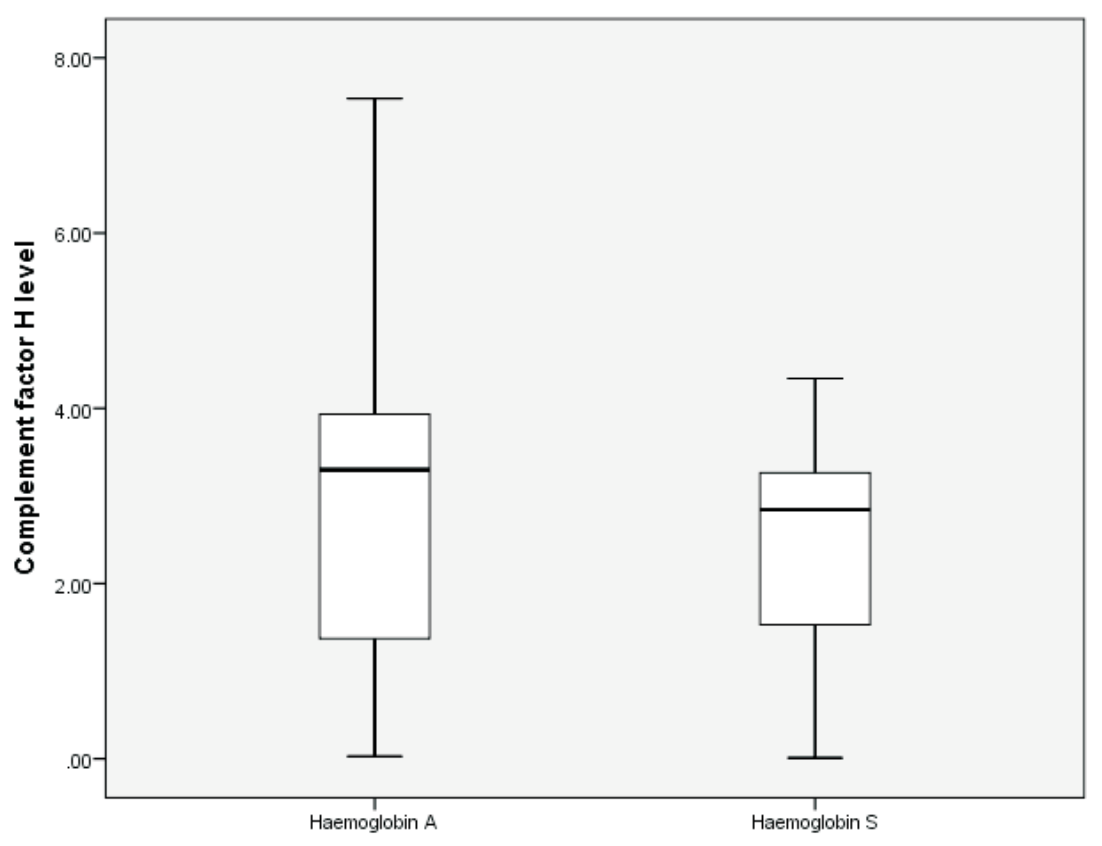

Figure 2: Complement Factor $H$ levels in haemoglobin $A$ and haemoglobin $S$

This box plot illustrates median values of complement factor $\mathrm{H}$ in patients and control. The median complement factor $H$ level for patients was $2.8 \mathrm{ng} / \mathrm{mL}$ and for controls was $3.2 \mathrm{ng} / \mathrm{mL}$ 